

DEN NORSKE LEGEFORENING

\title{
Veileder, retningslinje, prosedyre
}

SPRÅKSPALTEN

\section{MAGNE NYLENNA}

E-post: magne@nylenna.no

Magne Nylenna (f. 1952) er bl.a. redaktør av Medisinsk ordbok og medlem av Gruppe for norsk medisinsk fagspråk.

Faglige anbefalinger i helsetjenesten har som formål å kvalitetssikre og standardisere virksomheten. Også betegnelsene på slike anbefalinger bør kvalitetssikres og standardiseres bedre.

Helsetjenesten styres hovedsakelig gjennom rettslige virkemidler (lover, forskrifter, avtaler etc.), økonomiske virkemidler (bevilgninger, budsjetter, finansieringsordninger etc.) og organisatoriske virkemidler. I økende grad brukes også faglige styringsmidler i form av normerende anbefalinger som kan utarbeides av nasjonale helsemyndigheter, institusjoner, fagmiljøer, profesjonsgrupper eller andre. Målet er å redusere uønsket variasjon og å bedre kvaliteten i tjenestene.

Både formen og betegnelsen på slike dokumenter varierer, og autoriteten av anbefalingene vil avhenge av hvem som står bak, og hvordan dokumentene er formulert.

Betegnelsene på slike anbefalinger er neppe alltid like gjennomtenkte, og terminologien er dårlig standardisert. Ikke minst er helsemyndighetenes terminologi innen kreftomsorgen forvirrende. Her benyttes blant annet betegnelser som handlingsplan, handlingsprogrammer, pakkeforløp og screeningprogram (1).

Verken språkspalten eller forfatteren er gitt noen definisjonsmakt på dette området. Dette forsøket på en avklaring bygger på inntrykk og refleksjoner etter å ha lest mange dokumenter med ulike betegnelser, og innebærer et ønske om mer entydige betegnelser.

De mest overordnede dokumentene er de nasjonale strategiene, for eksempel Nasjonal strategi for innvandreres helse (2) og strategien for ikke-smittsomme folkesykdommer (3) som inneholder politiske mål. Tre betegnelser går igjen på de mer konkrete anbefalingene, nemlig veileder, retningslinje og prosedyre ( $\operatorname{tab} 1)(4)$. Flere sykehus samler slike anbefalinger $\mathrm{i}$ en metodebok.

\section{Tabell 1}

Veiledere, retningslinjer og prosedyrer kan betraktes som deler av et hierarki, slik disse eksemplene viser. Veiledere er mest omfattende og overordnet, og prosedyrer er mest 


\begin{tabular}{|ll|}
\hline Veileder & $\begin{array}{l}\text { Overordnet, oftest omfattende dokument som gir organisatoriske og/eller } \\
\text { faglige føringer, gjerne på nasjonalt nivå, for et fagområde, for eksempel } \\
\text { Vaksinasjonsveilederen fra Folkehelseinstituttet. }\end{array}$ \\
\hline Retningslinje & $\begin{array}{l}\text { Systematisk utarbeidet og normgivende anbefaling først og fremst for } \\
\text { håndtering av en klinisk problemstilling eller situasjon, for eksempel } \\
\text { Nasjonal faglig retningslinje for diabetes fra Helsedirektoratet. }\end{array}$ \\
\hline Prosedyre & $\begin{array}{l}\text { Detaljert beskrivelse av en fremgangsmåte for å utføre en bestemt og } \\
\text { avgrenset aktivitet eller en prosess, for eksempel Sårstell av venøse leggsår } \\
\text { fra Oslo universitetssykehus. }\end{array}$ \\
\hline
\end{tabular}

\section{Veileder}

Veileder er den minst presise betegnelsen. En veileder kan være et relativt overordnet dokument som gir føringer på et bredt område, gjerne både organisatorisk og medisinsk. Anbefalinger om pasientrettigheter og tidsfrister for helsehjelp i spesialisthelsetjenesten kalles for eksempel prioriteringsveiledere (5). «Overordnet» kan bety at anbefalingene er generelle, og at målgruppen er stor, som Helsedirektoratets Veileder om rehabilitering, habilitering, individuell plan og koordinator (6). Det kan også bety at dokumentet er omfattende, nærmest en oppslagsbok, som Smittevernveilederen (7) fra Folkehelseinstituttet, eller en samling retningslinjer som Norsk barnelegeforenings Generell veileder i pediatri (8).

En veileder kan også være en utdypning av en forskrift, en beskrivelse av anbefalte organiseringsformer, eller en bruksanvisning til hjelp i en søknadsprosess, en utdanning eller lignende.

\section{Retningslinje}

En retningslinje (guideline på engelsk) har som regel et smalere og mer handlingsrettet innhold enn en veileder og er oftest knyttet til kliniske problemstillinger.

I Helsedirektoratets veileder (!) for utvikling av kunnskapsbaserte retningslinjer definerer man slike dokumenter som «systematisk utarbeidede råd og anbefalinger knyttet til forebygging, diagnostikk, behandling og/eller oppfølging av pasient-, bruker- eller diagnosegrupper innenfor helse og omsorgstjenestene» (9). Retningslinjer utarbeides av fagmiljøer, profesjonsforeninger, helseinstitusjoner og myndigheter. Det er bare Helsedirektoratet som har mandat til å lage nasjonale faglige retningslinjer.

Anbefalingene som gis i slike nasjonale retningslinjer er ikke rettslig bindende, «men beskriver nasjonale helsemyndigheters oppfatning av for eksempel hva som er god faglig praksis, hvordan relevant regelverk skal tolkes og hvilke prioriteringer mv. som er i samsvar med vedtatt politikk for helse- og omsorgstjenesten» (10).

\section{Prosedyre}

En prosedyre er en fremgangsmåte for å utføre en aktivitet eller en prosess (11). Mens retningslinjer angir hva som bør gjøres i gitte situasjoner, er prosedyrer konkrete beskrivelser av hvordan avgrensede oppgaver bør utføres. Prosedyrer kan i tillegg til å beskrive en anbefalt metode også inneholde detaljert informasjon om hvem som skal gjøre hva, hvor nødvendig utstyr finnes, aktuelle navn, telefonnummer etc.

Tradisjonelt er prosedyrer i helsetjenesten blitt utarbeidet lokalt, for eksempel i sykehusavdelinger, noe som har gitt et mangfold av anbefalinger av hvordan samme oppgave bør løses. Et nasjonalt nettverk for å samordne og kvalitetssikre utarbeiding av fagprosedyrer har redusert antall ansatte ved helseforetakene som er involvert i slikt arbeid, men fra 2009 til 2016 har antall fagprosedyrer i spesialisthelsetjenesten likevel økt fra ca. 46 ooo til ca. 99 ooo (12). 
1. Helsedirektoratet. Kreft. https://helsedirektoratet.no/kreft (25.8.2017).

2. Likeverdige helse- og omsorgstjenester - god helse for alle. Nasjonal strategi om innvandreres helse 2013-2017. Oslo: Helse- og omsorgsdepartementet, 2013.

https://www.regjeringen.no/contentassets/2de7egefa8d341cfb8787a71eb15e2db/likeverdige_tjenester.p df(25.8.2017).

3. NCD-strategien. Oslo: Helse- og omsorgsdepartementet, 2013.

https://www.regjeringen.no/contentassets/e62aa5018afa4557ac5egf5e780o891f/ncd_strategi_o6og13.pd $\mathrm{f}(25.8 .2017)$.

4. Nylenna M. Medisinsk ordbok. 8. utg. Oslo: Kunnskapsforlaget, 2017.

5. Prioriteringsveiledere i spesialisthelsetjenesten.

https://helsedirektoratet.no/prioritering/prioriteringsveiledere-for-spesialisthelsetjenesten (25.8.2017).

6. Rehabilitering, habilitering, individuell plan og koordinator. IS-2651. Oslo: Helsedirektoratet, 2017. https://helsedirektoratet.no/retningslinjer/rehabilitering-habilitering-individuell-plan-og-koordinato r(25.8.2017).

7. Smittevernveilederen. https://www.fhi.no/nettpub/smittevernveilederen/ (25.8.2017).

8. Norsk barnelegeforening. Veileder i pediatri. Tromsø: Den norske legeforening, 2012. http://www.helsebiblioteket.no/retningslinjer/pediatri/forside (25.8.2017).

9. Veileder for utvikling av kunnskapsbaserte retningslinjer. IS-1870. Oslo: Helsedirektoratet, 2012. https://helsedirektoratet.no/retningslinjer/veileder-for-utvikling-av-kunnskapsbaserte-retningslinjer (25.8.2017).

10. Prop. 91 L (2010-2011). Lov om kommunale helse- og omsorgstjenester m.m. (helse- og omsorgstjenesteloven): 272. https://www.regjeringen.no/no/dokumenter/prop-91-l-20102011/id638731/ (25.8.2017).

11. Norges standardiseringsforbund. Systemer for kvalitetsstyring: grunntrekk (ISO 9000:200o). Oslo: Norges standardiseringsforbund, 2000.

12. Strand G. Prosedyrearbeid - fortsatt meningsløst mangfold? Om arbeid med fagprosedyrer i helseforetak i Norge. Masteroppgave. Oslo: Institutt for helse og samfunn, Det medisinske fakultet, Universitetet i Oslo, 2016.

https://www.duo.uio.no/bitstream/handle/10852/54050/Master-Grete-Strandnov-2016.pdf? sequence $=1$ (25.8.2017).

Publisert: 22. januar 2018. Tidsskr Nor Legeforen. DOI: 10.4045/tidsskr.17.0737

C Tidsskrift for Den norske legeforening 2020. Lastet ned fra tidsskriftet.no 